\title{
KNOWLEDGE AND FAITH VALUES AS PART OF EMPLOYEES' PERCEIVED VALUE IN ISLAMIC BANKS AND THEIR EFFECTS ON SATISFACTION AND PERFORMANCE
}

\author{
Hamid Wahyuniati ${ }^{\star}$, Tangalayuk Agustinus \\ Faculty Economy and Business, University of Halu Oleo, Kendari, Indonesia \\ *E-mail: wahyuniati@uho.ac.id
}

\begin{abstract}
The present study has two purposes. First, it intends to put forwards two new relevant dimensions of perceived value for Islamic banks, those are knowledge value and faith value. Second, it intends to explore their effects on satisfaction and performance in Islamic banks of Makassar. This study was conducted in Islamic bank employees in city Makassar, Indonesia. By using a sample of 40 respondents and SEM PLS is applied for data analysis. From the study, it is found that satisfaction has a partially mediating effect on the relationship between faith value and performance, and significantly mediating effect on that between knowledge value and performance. It is interesting that the research proposes two new variables, that is knowledge value and faith value, which can be considered as parts of perceived value, which would complement and enrich the theory of perceived value accordingly.
\end{abstract}

\section{KEY WORDS}

Knowledge value, faith value, perceived value, satisfaction, commitment.

Perceived value is important concept in human resources and marketing management literature, as it has a great potential to strengthen relationship of stakeholders to organization. Despite the importance of perceived value, the literature presents variety of its definitions, conceptualization and operationalization (Woodall, 2003). It is partly due to its broadness and context dependent nature (Woodall, 2003: 3). Every sector of business possesses its own unique perceived value different from those in other sectors.

(Sheth, J. N et al., 1991) for instance, introduced functional, emotional, social, epistemic, and conditional values for perceived value in consumption sector. (Petrick, J. F, 2002) pinpointed quality, emotional response, reputation obtained by acquiring the service, behavioral price, and monetary price for perceived value in recreational services. (Sánchez, $\mathrm{J}$ et al, 2006) have developed post-purchase perceived value consisting of functional value of the establishment, functional value of the contact personnel, functional value of the service quality, functional value price, emotional value and social value in tourism context. (Mathwick, C., et al, 2001) emphasized Visual appeal, entertainment, escapism, enjoyment, efficiency and economic value factors in internet shopping setting. Holbrook emphasized functional, social, hedonist and spiritual construct for religion-related sectors.

The present study highlights perceived value of Islamic banks within the perspective of their employees. Taking account of Islamic bank's nature, the study looks into knowledge value and faith value as some conspicuous values along with other values as they are so far absent in mainstream perceived value concept. By knowledge value here means the perception that an organization values, recognizes, enriches and manages all necessary knowledge that increase human resources and service quality. Regarding knowledge value, the bulk of Islamic banks lag behind conventional ones in terms efficiency and competitiveness due to its nascence and complex contracts. The effort to address this issue heightens perception that the organization has commitment for service quality that leads to employees' increased performance. This is especially so, as Islamic banking is regarded as a specialized area of banking since it is based on true Islamic economic principles. However, there is an increasing gap between existing and required level of expertise in Islamic banks (Ishaq Bhatti, M., et al., 2011). In Pakistan case, (Ishaq Bhatti, M et al., 2011) argued that it were conventional banking professional who progressed Islamic banking. However, gap still exists between for existing human resources with specialized knowledge about Islamic 
banking principles and the expectation level to handle Islamic banking complex funding modes. Their study revealed gap of expertise in this Islamic banking and implies that top management of Islamic banks should have high resource commitment for training and development of their people regarding Sharia fundamentals, product knowledge, problemsolving techniques and interpersonal skills and modes of financing. It also highlights the lack of innovation and creativity of the Islamic banks (Ayedh and Echchabi, 2015).

As to faith value, an organization should take account of employees' welfare as it increases their motivation and commitment. Islam teaches the importance of happiness (Falah) and becomes one of those warranted by Islamic banks. Happiness grounded on healthy soul is one of Islamic principles that every Moslem people should accomplish. In their interview research stage with Islamic bank employees, (Khajar and Munadjat, 2017) found that the basic intention for the employees to develop careers in Islamic banks is to keep the faith. It enables them to retain happiness, as it engenders a sense of security for the feeling that they are able to perform the Islamic duties. Having religion and attempts to practice its teachings in day-to-day life, including workplace, a human characteristic (Khajar and Munadjat, 2017).

With knowledge value and faith value as parts of Islamic banks' perceived value along with other values which are beyond this study's scope analysis, the present study intends to explore their effects on satisfaction and organizational performance. The results will surely enrich human resources management literature especially pertaining to Islamic banking that accentuates more knowledge and faith values.

\section{THEORETICAL REVIEW AND HYPOTHESES}

Perceived value is individual's perception based on evaluation of comparison between accepted benefits and sacrifice to achieve those benefits" (Sumaedi et al., 2014 b). Many authors have different dimensions depending on the scope and nature of sectors under study. The following is the summary of perceived value dimensions that every author has designed.

Table 1 - Dimensions of Perceived Value

\begin{tabular}{|l|l|}
\hline Dimensions & Author(s) \\
\hline Hedonic value, utilitarian value & Holbrook and Corfman, 1985 \\
\hline Acquisition value, transaction value & Monroe and Chapman, 1987 \\
\hline Functional, emotional, conditional, social, epistemic & Sheth et al., 1991 \\
\hline Tangibles values, intangibles values & Nilson, 1992 \\
\hline Hedonic value, utilitarian value & Babin et al., 1994 \\
\hline Expected value, received value & Kotler et al., 1995 \\
\hline Pre-use value, post-use value & Lovelock, 1996 \\
\hline $\begin{array}{l}\text { Benefits (quality, satisfaction and specific benefits), costs (money, } \\
\text { time and effort) }\end{array}$ & Zeithaml and Bitner, 1996 \\
\hline $\begin{array}{l}\text { Emotional or intrinsic value, functional or extrinsic value, logical or } \\
\text { value for money }\end{array}$ & Woodruff, 1997 \\
\hline Functional, emotional & Gronroos, 1997 \\
\hline Quality, price, acquisition, transaction & Grewal et al., 1998 \\
\hline $\begin{array}{l}\text { Efficiency, excellence, play, aesthetics, Status,esteem, ethics, } \\
\text { spirituality }\end{array}$ & Holbrook, 1999 \\
\hline Consumption value, extended value & Oliver, 1999 \\
\hline $\begin{array}{l}\text { Adquisition value, transaction value, value “in-use", redemption } \\
\text { value }\end{array}$ & $\begin{array}{l}\text { Parasuraman and Grewal, } \\
\text { 2000 }\end{array}$ \\
\hline Functional- quality, functional-price, emotional, special PERVAL & Sweeney and Soutar, 2001 \\
\hline $\begin{array}{l}\text { Quality, monetary price, behabioral price, emotional, reputation } \\
\text { SERV-RERVAL }\end{array}$ & Petrick, 2002 \\
\hline $\begin{array}{l}\text { Active values (efficiency; economic value and enjoyment); Reactive } \\
\text { values (visual attraction; entertainment value and service excellence) }\end{array}$ & Mathwick et al., 2002 \\
\hline Functional, emotional, social GLOVAL & Sanchez et al, 2006 \\
\hline
\end{tabular}

Source: Dimutrela, 2013. 
To grasp the role perceived value might play in the relationship between individuals and products or organization, means-end approach might be of a great help. Means-end chain theory holds that every individual evaluates relevant attributes and benefits of a product or organization. It was developed by (Gutman, J, 1982) with basic idea that value is a dominant factor in individuals' relationship decisions. That is, they evaluate a product or organization based on its functions or values, and whether their interaction with it leads to desired consequences. Evaluation of the consequences would determine the relationship. This evaluation drives for a closer relationship based on certain purposes (Koo, D. M, 2006), such as security, belongingness, or similarity. High perceived value would result in heightened positive affection toward the product or organization (Fornell et al., 1996). In this case, values perceived by individuals over a product or organization are the main point of evaluation for further relationship (Hsin Chang, $\mathrm{H}$ and Wang, $\mathrm{H}, 2011$ ).

It was developed by (Gutman, J, 1982) to emphasize that individuals make use of values or benefits of a product or organization to minimalize negative consequences and maximize positive consequences. It means that individuals naturally seek product or organization with better values compared to others. In this case, it can be inferred that there is a relationship between individual's perceived value and their decision to make further intimate contacts (Hsin Chang, $\mathrm{H}$ and Wang, $\mathrm{H}, 2011$ ). Some researches applied means-end theory to grasp satisfaction. They are for example, (Lopez-Mosquera, N and Sanchez, M, 2012; Gallarza et al., 2009). Others also applied the same theory to explore motivation which might represent performance. Those are for example XX.

Perceived value and satisfaction is inseparable, as satisfaction engenders when expected values are fulfilled. Satisfaction might be the antecedent or the consequence of value. In the context of the present study, satisfaction holds position as the consequence of received value because employees should experience the values that make them motivated to increase performance. Several works have examined relationship between perceived value and satisfaction such as (Parahoo, S. K et al., 2015; Setijono, D and Dahlgaard, J. J, 2007; Mosavi and Ghaedi, 2012; Sumaedi et al., 2016; Dmitrovic et al., 2007; Bontis et al., 2007; Chen, C. F and Tsai, D. C, 2007). While those between perceived value and performance include (Kennedy, G. J and Tuckman, B. W, 2013; Zhang and Nankai, 2014; Matanda and Ndubisi, 2009; Wan, E. W et al., 2016). More specifically, the works that explored the relationship between knowledge and performance include (Lopez-Mosquera, $\mathrm{N}$ and Sanchez, M, 2012; Gravier et al., 2008; Mills, A. M and Smith, T. A, 2011; Rahman et al., 2015).

Hypotheses:

- H1: Knowledge Value is considered to have a significant effect on employees' satisfaction in Islamic banks;

- H2: Faith value is considered to have a significant effect on employees' satisfaction in Islamic banks;

- H3: Knowledge Value is considered to have a significant effect on employees' Performance in Islamic banks;

- H4: Faith value is considered to have a significant effect on staff performance in Islamic banks.

Lee, Y. K et al. (2006) argument that employee satisfaction leads to heightened quality customer service quality and enhance employee retention and commitment. Job satisfaction is reflected by the presence of positive emotion or enjoyment in the job (Locke, 1976) and affective feeling about the job (Spector, 1997). These emotions might lead individuals to contribute more to their works. Employee satisfaction engenders employee motivation. Several works have investigated relationship between work satisfaction and performance, such as (Gu and Siu, 2009; Sawitri et al., 2016; Siengthai and Pila-Ngarm, 2016). The present study hypothesizes that.

H5: Islamic satisfaction is considered to have a significant effect on staff performance. 


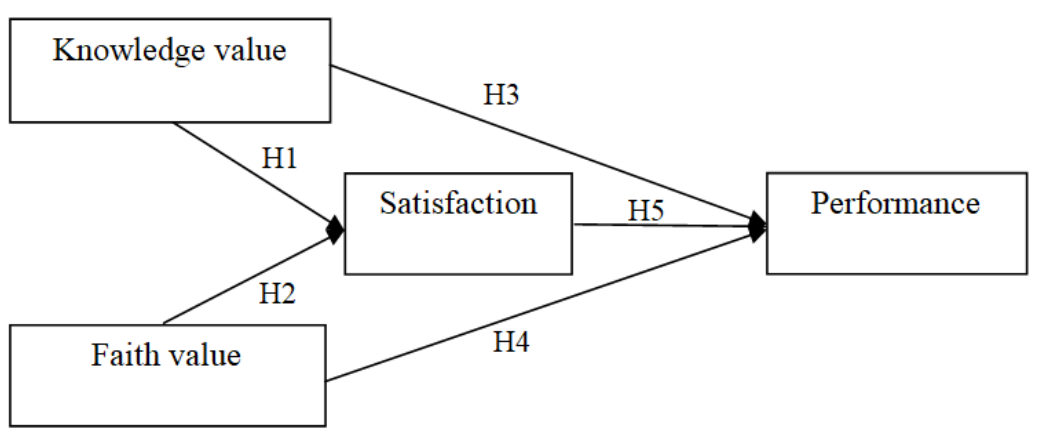

Figure 1 - Conceptual Framework

\section{METHODS OF RESEARCH}

The present study designs two new constructs of perceived value deemed relevant for Islamic bank within the employees' perspectives. They result from previous interviews conducted before the research, and content validity and face validity are carried out subsequently to make sure their validity and reliability. Content validity involves expert judgment in which seven experts give their evaluation on the respective construct. The resulting constructs is further tested by referring the 40 respondents' opinions of their properness.

As an exploratory study, the investigation used the convenience sampling method to collect data Islamic bank employees Makassar, Indonesia. According to (Zikmund, 1996), convenience sampling refers to the sampling method of obtaining information from the people or units that are most conveniently available. Researchers generally use convenience samples to gather a large number of completed questionnaires fast and cost efficient. The respondents are chosen based on their religion and working more than 5 years. Islamic banks are spread over the region, and investigation should include them and cover all staff to accommodate their attitudes and ways of life. This study uses SEM PLS for data analysis because in this study using a model formed on the conceptual framework.

\section{RESULTS OF STUDY}

The study conceives that knowledge value and faith value have a significant effect on satisfaction. Employees' satisfaction is also predicted to have a significant effect on employees' performance. More importantly, it conceives that satisfaction has a partially mediating effect on the relationship between faith value and performance, and has significantly mediating effect on that between knowledge value and performance. It means that faith value have matters so much to Islamic bank employees. They commonly have decided that working in Islamic bank is suitable to their social and emotional ideals and would strengthen their religion faith, including relevant values such as contribution to religion teachings that forbid interest-based loans and channeling the funds to companies operating in religion-forbidden sectors like alcohol and pork-foods. By joining this organization, they think they might keep and even strengthen their faith, and eventually might lead to emotional well-being. They commonly have less expectation of knowledge contribution and development as mainstream thinking holds that Moslem are not encouraged to stray from basic Islam guidelines. Obedience and difficulties in implementing other Sharia conventions such as Mudharabah and Musharakah. So far, Islamic banks only focus on Murabahah and the like.

\section{DISCUSSION OF RESULTS}

From the results above, it might be conceived that Islamic satisfaction serves only partial mediation on the relationship between faith value and performance. It also hold on the relation between knowledge value and performance. 
Managers should take account more on faith value and knowledge value, beside other existing values, as part of perceived value in Sharia banks. It is important as it contributes to management literature concerning perceived value, especially in Islamic banking. They also need to design condition that makes knowledge and faith values complementary. The capability to contribute, develop and make use of knowledge is emphasized in Islamic teaching and might add to faith, and thus joy of accomplishing religion duty.

Thus, Islamic bank should also a place of innovation where all changes are possible without violating Sharia rules. There should be a synergy between banks, university, Islamic intellectual bodies, and Islamic figures in finding converging points of innovations. So far divergent opinions and competing interpreting verses have impeded consensus. Attempts should be made to decrease divergences, so that any possible innovation is feasible in terms of its operationalization and sustainability.

Future research. Relationship between faith value and knowledge value should be further explored by future researches. It is logical as Islamic teaching also appreciates the drive to make some changes, other word for innovation, to the benefit of progress and society at large. Capability to make positive system-sized changes equates to make contribution to the progress of Islam. People with this perspective will have positive change orientation, as this also strengthen their faith. Contribution in the form of positive change is also a prayer to the God.

Comparing these values to others is also important. Social or epistemic values might play equally important parts, and their contribution parts will surely add valuable knowledge of perceive value laddering commonly made by employees in Islamic banks. Employees in different positions are also important to be accounted of, as they might have different perceived value preferences.

\section{CONCLUSION}

Islamic banks should take account of knowledge value. If they have shown a consistent commitment to change the organization conditions by providing continuous training, conducting rigorous knowledge management, and emphasizing the real Islamic products, the employees might start to look at knowledge value such essential that it would determine their satisfaction. There are some possibilities that make knowledge value subordinate. For one, they might already assume that there is not much to be expected from Islamic banks in terms of knowledge and creativity. It is in line with the work of (Ayedh and Echchabi, 2015) who said that Islamic bank commonly suffer from the lack of innovation and creativity of the Islamic banks' compared to conventional ones, as they are unable to provide proposals of alternative banking instruments. It would not be easy as it takes prolonged process.

\section{REFERENCES}

1. Chen, C. F., \& Tsai, D. C. (2007). How destination image and evaluative factors affect behavioral intentions? Tourism Management, 28(4), 1115-1122. https://doi.org/10.1016/j.tourman.2006.07.007

2. Dmitrović, T., Knežević Cvelbar, L., Kolar, T., Makovec Brenčič, M., Ograjenšek, I., \& Žabkar, V. (2009). Conceptualizing tourist satisfaction at the destination level. International Journal of Culture, Tourism and Hospitality Research, 3(2), 116-126. https://doi.org/10.1108/17506180910962122

3. Fornell, C., Johnson, M. D., Anderson, E. W., Cha, J., \& Bryant, B. E. (1996). The American Customer Satisfaction Index: Nature, Purpose, and Findings. Journal of Marketing, 60(4), 7. https://doi.org/10.2307/1251898

4. Gravier, M. J., Randall, W. S., \& Strutton, D. (2008). Investigating the role of knowledge in alliance performance. Journal of Knowledge Management, 12(4), 117-130. https://doi.org/10.1108/13673270810884291

5. Gutman, J. (1982). A Means-End Chain Model Based on Consumer Categorization Processes. Journal of Marketing, 46(2), 60. https://doi.org/10.2307/3203341 
6. Hsin Chang, H., \& Wang, H. (2011). The moderating effect of customer perceived value on online shopping behaviour. Online Information Review, 35(3), 333-359. https://doi.org/10.1108/14684521111151414

7. Ishaq Bhatti, M., Zafarullah, M., Awan, H. M., \& Bukhari, K. S. (2011). Employees' perspective of organizational service quality orientation: Evidence from Islamic banking industry. International Journal of Islamic and Middle Eastern Finance and Management, 4(4), 280-294. https://doi.org/10.1108/17538391111186537

8. Kennedy, G. J., \& Tuckman, B. W. (2013). An exploration into the influence of academic and social values, procrastination, and perceived school belongingness on academic performance. Social Psychology of Education, 16(3), 435-470. https://doi.org/10.1007/s11218-013-9220-z

9. Koo, D. M. (2006). The fundamental reasons of e-consumers' loyalty to an online store. Electronic Commerce Research and Applications, 5(2), 117-130. https://doi.org/10.1016/j.elerap.2005.10.003

10. Lee, Y. K., Nam, J. H., Park, D. H., \& Lee, K. A. (2006). What factors influence customeroriented prosocial behavior of customer-contact employees? Journal of Services Marketing, 20(4), 251-264. https://doi.org/10.1108/08876040610674599

11. Lopez-Mosquera, N., \& Sanchez, M. (2012). The role of satisfaction and emotional response in the choice mechanisms of suburban natural-areas users. Environmental Management, 49(1), 174-191. https://doi.org/10.1007/s00267-011-9753-x

12. Mathwick, C., Malhotra, N., \& Rigdon, E. (2001). Experiential value: Conceptualization, measurement and application in the catalog and Internet shopping environment. Journal of Retailing, 77(1), 39-56. https://doi.org/10.1016/S0022-4359(00)00045-2

13. Mills, A. M., \& Smith, T. A. (2011). Knowledge management and organizational performance: A decomposed view. Journal of Knowledge Management, 15(1), 156-171. https://doi.org/10.1108/13673271111108756

14. Parahoo, S. K., Al-Nakeeb, A., \& Onagun, I. (2015). We are who we are: Incorporation of individual culture in customer satisfaction models. Journal of Financial Services Marketing, 20(3), 220-230. https://doi.org/10.1057/fsm.2015.15

15. Pérez-López, S., \& Alegre, J. (2012). Information technology competency, knowledge processes and firm performance. Industrial Management and Data Systems, 112(4), 644-662. https://doi.org/10.1108/02635571211225521

16. Petrick, J. F. (2002). Development of a Multi-Dimensional Scale for Measuring the Perceived Value of a Service. Journal of Leisure Research, 34(2), 119-134. https://doi.org/10.1080/00222216.2002.11949965

17. Sanchez, J., Callarisa, L., Rodríguez, R. M., \& Moliner, M. A. (2006). Perceived value of the purchase of a tourism product. Tourism Management, 27(3), 394-409. https://doi.org/10.1016/j.tourman.2004.11.007

18. Setijono, D., \& Dahlgaard, J. J. (2007). Customer value as a key performance indicator (KPI) and a key improvement indicator (KII). Measuring Business Excellence, 11(2), 4461. https://doi.org/10.1108/13683040710752733

19. Sheth, J. N., Newman, B. I., \& Gross, B. L. (1991). Why we buy what we buy: A theory of consumption values. Journal of Business Research, 22(2), 159-170. https://doi.org/10.1016/0148-2963(91)90050-8

20. Wan, E. W., Chan, K. W., \& Chen, R. P. (2016). Hurting or helping? The effect of service agents' workplace ostracism on customer service perceptions. Journal of the Academy of Marketing Science, 44(6), 746-769. https://doi.org/10.1007/s11747-015-0466-1 